\title{
HUBUNGAN PENGETAHUAN PERILAKU PERSONAL HYGIENE IBU DENGAN KEJADIAN DIARE PADA BALITA
}

\author{
Knowledge of Behavior Mother's Personal Hygiene Correlation To Diarrhea \\ Incident of Infants
}

\author{
Nuri Vitriawati ${ }^{1}$, Dewi Arradini ${ }^{2}$ \\ STIKes Mitra Husada Karanganyar \\ (dewiarra29@gmail.com)
}

\begin{abstract}
ABSTRAK
Latar Belakang : Pengetahuan tetang perilaku personal hygiene ibu adalah penting dan harus dilakukan dengan kesadaran dan kontinyu untuk memelihara kebersihan dan kesehatan diri untuk ibu dan yang terpenting adalah untuk balitanya. Mengingat balita adalah individu yang rentan, belum mandiri, dan pasif (belum bisa melakukan segala sesuatu tanpa bantuan dari ibunya). Kejadian diare yang dialami oleh balita masih banyak terjadi dikarenakan perilaku personal hygiene ibu yang masih kurang.

Tujuan : Penelitian ini dilakukan untuk mengetahui hubungan antara pengetahuan perilaku personal hygiene ibu dengan kejadian diare pada balita di Desa Kaling, Tasikmadu.

Metode : Penelitian ini menggunakan metode observasional analitik dengan pendekatan cross sectional dengan jumlah populasi sebanyak 297 balita, dan sampel berjumlah 75. Instrumen yang digunakan adalah kuisioner. Analisis data dilakukan secara univariat dan bivariat (menggunakan uji chi square dengan $\alpha=0,05)$.

Hasil : Perilaku personal hygiene ibu terhadap balitanya masih kurang, dan penelitian menunjukkan ada hubungan antara perilaku personal hygiene ibu dengan kejadian diare pada balita dengan $p$ value $=0,000<0,05$ dan nilai $\mathrm{X}^{2}$ hitung sebesar 26.390 sedangkan $X^{2}$ tabel pada $\mathrm{df}=2$ sebesar 5,991 sehingga $\mathrm{X}^{2}$ hitung $>\mathrm{X}^{2}$ tabel. Kesimpulan : Perilaku personal hygiene ibu yang buruk akan meningkatkan kejadian diare pada balita.
\end{abstract}

Kata Kunci: perilaku personal hygiene, kejadian diare

\begin{abstract}
Background : Knowledge abaout behavior mother's personal hygiene is important, and must to do with consciousness and continuously to maintan cleanliness and health themselves to mother and is primarily for the infants. Infants is susceptible, still dependent and passive person (they can not do anything without help from their mother). Diarrea on infants are still many occurred due to personal hygiene beaviour of the mother that were lacking.
\end{abstract}


The Purpose : The purpose of this study to find correlation between knowledge of behavior mother's personal hygiene with incident of diarrea on infants at Kaling village area Tasikmadu.

Method : This study used observation analytic and cross sectional study, the population is all infants in Kaling village areas in 2018 there are 297, The sample that used 75 respondents. The instrument of the study were using questionnaire. Data were analyzed univariate and bivariate (using chi square test with $\alpha=0,005$ ). Result : This study indicating that there is a correlation between behavior mother's personal hygiene with the incident of diarrhea in Kaling village area with $p$ value $=0,000<0,05$.

Conclusion is poor personal hygiene of mother will incrase the incident of diarrhea in children.

Keywords: diarrhea, personal hygiene, incident of diarrhea

\section{PENDAHULUAN}

Dalam kehidupan sehari-hari kebersihan merupakan hal yang sangat penting dan harus diperhatikan karena kebersihan akan mempengaruhi kesehatan dan psikis seseorang. Kebersihan itu sendiri sangat berpengaruh diantaranya kebudayaan, sosial,keluarga, pendidikan. Persepsi seseorang terhadap kesehatan,serta perkembangan (dalam Tarwoto \& Wartonah 2006).

Praktik hygiene sama dengan peningkatan kesehatan. Dengan implementasi tindakan hygiene pasien, atau membantu anggota keluarga untuk melakukan tindakan itu dalam lingkungan rumah sakit, perawat menambah tingkat kesembuhan pasien. Dengan mengajarkan cara hygiene pada pasien, pasien akan berperan aktif dalam meningkatkan kesehatan dan partisipan dalam perawatan diri ketika memungkinkan (Perry \& Potter, 2005).

Jika seseorang sakit, biasanya masalah kebersihan kurang diperhatikan. Hal ini terjadi karena kita menganggap masalah kebersihan adalah masalah sepele ,padahal jika hal tersebut dibiarkan terus dapat mempengaruhi kesehatan secara umum ( dalam Tarwoto \& Wartonah 2006).

Personal hygiene dilakukan untuk melindungi tubuh dari masuknya kuman kedalam tubuh manusia. Perilaku personal hygiene ibu dapat mempengaruhi kesehatan pada balita, diantaranya kebiasaan ibu mencuci tangan menggunakan sabun, perilaku ibu menjaga kebersihan kuku, kebiasaan dalam memberi makanan anak balita yang meliputi pengolahan makanan, menjaga bahan makanan dan penyimpanan makanan balita pada suhu kamar yang semestinya (Siary dalam Diah E, 2013).

Kebiasaan mencuci tangan berpengaruh terhadap kondisi kesehatan pada balita, hal ini disebabkan karena balita rentan terhadap mikrooorganisme, berbagai agen infeksius dan segala aktivitas anak yang dibantu ibu, sehingga cuci tangan sangat diperlukan oleh ibu sebelum dan sesudah kontak dengan anak (Kusuma dalam Mokodompit, 2015). Perilaku personal hygiene ibu yang buruk dapat menyebabkan masalah kesehatan pada balita salah satunya adalah diare. Perilaku personal hygiene yang buruk mempunyai resiko 6,287 kali lebih besar menderita 
diare dibandingkan dengan balita yang tinggal dengan kondisi personal hygiene yang baik (Profil Kesehatan Provinsi Jawa Tengah, 2016).

Insiden diare pada balita di Indonesia sebanyak 6,7\%. Lima provinsi dengan insiden diare tertinggi adalah Aceh 10,2\%, Sulawesi Selatan 8,1\%, Papua 9,6\%, DKI Jakarta 8,9\% dan Banten 8,0\%. Sedangkan provinsi Jawa Tengah sebesar 4,7\%. Karakteristik diare balita tertinggi terjadi pada kelompok umur 12 - 23 bulan 7,6\% (Riskesdas, 2013). Insiden kasus diare di Jawa Tengah pada tahun 2016 penemuan kasus tertinggi adalah kota Tegal 221,6\%, Pekalongan 144,4\% dan Kendal 123,2\%, sedangkan kabupaten Karanganyar masuk dalam 13 besar dengan angka kejadian diare sebanyak 80,0\% (Profil Kesehatan Provinsi Jawa Tengah, 2016).

Hasil studi pendahuluan yang dilakukan pada bulan Oktober 2018 ditemukan kasus diare sebanyak 187 dari bulan Februari sampai bulan September 2018 dipuskesmas Tasikmadu. Kasus diare pada balita terbanyak terjadi di desa Kaling yaitu sebanyak 32 kasus. Berdasarkan latar belakang diatas, maka peneliti tertarik untuk mencari tahu apakah terdapat hubungan perilaku personal hygiene ibu dengan kejadian diare pada balita di desa Kaling Kecamatan Tasikmadu.

\section{METODE PENELITIAN}

Jenis penelitian ini adalah observasional analitik dengan menggunakan pendekatan cross sectional yang bertujuan untuk mengetahui hubungan antar variabel.Populasi dalam penelitian ini adalah seluruh ibu yang memiliki balita dengan usia 12-59 bulan yang berada di desa Kaling yaitu berjumlah 297 orang. Adapun sampel dalam penelitian ini adalah sebagian ibu yang memiliki balita yang berusia 12-59 bulan, sebanyak 75 responden. Jumlah sampel ini diambil menggunakan teknik cluster random sampling.

Instrumen dalam penelitian ini berupa kuisioner terbuka dengan menggunakan skala Guttman. Kuisioner berupa daftar pertanyaan dimana telah tersedia pilihan jawaban ya dan tidak. Jika ya diberi skor 1 dan tidak diberi skor 0 untuk pertanyaan positif (favorable). Jika pertanyaan negatif (unfavorable), jika ya diberi skor 0 dan tidak diberi skor 1 (Arikunto dalam Dewi I,2016)

\section{HASIL DAN PEMBAHASAN}

1. Karakteristik Responden

Tabel 1. Karakteristik Responden Berdasarkan Usia

\begin{tabular}{|c|c|c|c|}
\hline No & Usia & Jumlah & Presentase $(\%)$ \\
\hline 1 & $<20$ Tahun & 6 & 8,0 \\
\hline 2 & 20-35 Tahun & 56 & 74,7 \\
\hline 3 & $>35$ Tahun & 13 & 17,3 \\
\hline \multicolumn{2}{|c|}{ Total } & 75 & 100 \\
\hline
\end{tabular}

Berdasarkan tabel 1 dapat diketahui bahwa mayoritas responden di Desa Kaling Kecamatan Tasikmadu berusia 20-35 tahun berjumlah 56 orang 
$(74,7 \%)$, usia $>35$ tahun sejumlah 13 orang $(17,3 \%)$ dan usia $<20$ tahun sejumlah 6 orang $(8,0 \%)$.

Tabel 2. Karakteristik Responden Berdasarkan Pendidikan

\begin{tabular}{clcc}
\hline No & Pendidikan & Jumlah & Presentase (\%) \\
\hline 1 & SD & 14 & 18,7 \\
2 & SMP & 36 & 48,0 \\
3 & SMA & 25 & 33,3 \\
& Total & 75 & 100 \\
\hline
\end{tabular}

Berdasarkan tabel 2. menunjukkan mayoritas responden berpendidikan SMP sederajat sejumlah 36 orang $(48,0 \%)$, SMA sederajat sejumlah 25 orang $(33,3 \%)$ dan berpendidikan SD sejumlah 14 orang $(18,7 \%)$.

Tabel 3. Karakteristik Responden Berdasarkan Pekerjaan

\begin{tabular}{clcc}
\hline No & Pekerjaan & Jumlah & Presentase (\%) \\
\hline 1 & IRT & 42 & 56,0 \\
2 & Bekerja & 33 & 44,0 \\
& Total & 75 & 100 \\
\hline
\end{tabular}

Berdasarkan tabel 3. diketahui bahwa jumlah responden sebagai IRT berjumlah 42 orang $(56,6 \%)$ dan yang berkerja sejumlah 33 orang $(44,0 \%)$.

2. Hasil Uji

Pada penelitian ini kuisioner yang digunakan harus diuji validitas untuk mengetahui sejauh mana instrumen mampu mengukur atribut yang seharusnya diukur. Selain itu, skala kuesioner juga harus diuji reliabilitasnya untuk menguji tingkat sejauh mana kestabilan hasil suatu pengukuran dapat dipercaya. Pengujian validitas dan reliabilitas pada penelitian ini juga dimaksudkan untuk menguji kesungguhan jawaban responden. Oleh sebab itu, dilakukan uji coba dahulu pada populasi diluar penelitian. Hasil uji validitas dapat diketahui bahwa dari 30 item yang diujikan, diperoleh indek korelasi $0,000-0,773$. Ada 3 item yang dinyatakan gugur yaitu 3,4,9 dikarenakan $p>$ 0,05 dengan taraf signifikansi $5 \%$ dan $\mathrm{N}=30$. Sedangkan reliabilitas skala yang ditunjukkan dengan koefisien Alpha sebesar 0,897.

Tabel 4. Hasil Uji Validitas dan Reliabilitas Perilaku Personal hygiene Ibu

\begin{tabular}{ccc}
\hline $\begin{array}{c}\text { Perilaku Personal Hygiene } \\
\text { Ibu }\end{array}$ & Validitas & Reliabilitas \\
\hline $\mathrm{N}=30$ & $-0,000-0,773$ & 0,897 \\
\hline
\end{tabular}

Untuk sebaran item perilaku personal hygiene ibu sebelum uji coba dapat dilihat pada tebel berikut :

Tabel 5. Sebaran Item Perilaku Personal Hygiene Ibu Sebelum Uji Coba

Hubungan Pengetahuan Perilaku Personal Hygiene Ibu Dengan Kejadian Diare Pada Balita (Nuri Vitriawati, Dewi Arradini) 
Avicenna Journal of Health Research. Vol 2 No 2. Oktober 2019 ( 25 - 33 )

\begin{tabular}{llccc}
\hline No & \multicolumn{1}{c}{ Indikator } & Pernyataan favorable & $\begin{array}{c}\text { Pernyataan } \\
\text { unfavorable }\end{array}$ & Jumlah \\
\hline 1 & Kebersihan tangan & $2,6,8,5$ & $1,3,4,7,9$ & 9 \\
2 & Kebersihan kuku & $10,11,15$ & $12,13,14$ & 6 \\
3 & Bahan makanan & $16,20,21,22,23$ & $17,18,19$ & 8 \\
4 & Kebiasaan memberi & $24,27,30$ & $25,26,28,29$ & 7 \\
& makan anak & 15 & 15 & 30 \\
\hline
\end{tabular}

Adapun sebaran item perilaku personal hygiene ibu setelah uji coba dapat dilihat pada tabel berikut :

Tabel 6 Sebaran Item Perilaku Personal Hygiene Ibu Setelah Uji Coba

\begin{tabular}{llccc}
\hline No & \multicolumn{1}{c}{ Indikator } & Pernyataan favorable & $\begin{array}{c}\text { Pernyataan } \\
\text { unfavorable }\end{array}$ & Jumlah \\
\hline 1 & Kebersihan tangan & $2,6,8,5$ & 1,7 & 6 \\
2 & Kebersihan kuku & $10,11,15$ & $12,13,14$ & 6 \\
3 & Bahan makanan & $16,20,21,22,23$ & $17,18,19$ & 8 \\
4 & $\begin{array}{l}\text { Kebiasaan memberi } \\
\text { makan anak }\end{array}$ & $24,27,30$ & $25,26,28,29$ & 7 \\
& Total & 15 & 12 & 27 \\
\hline
\end{tabular}

3. Analisa Univariat

Analisis univariat digunakan untuk mendeskripsikan variabel perilaku personal hygiene ibu dan kejadian diare pada balita.

a. Tingkat Perilaku Personal Hygiene Ibu

Berdasarkan data hasil kuesioner perilaku personal hygiene ibu menunjukkan bahwa dari 75 responden dapat dibagi menjadi 3 kategori yaitu kategori baik, cukup dan kurang. Berikut ini tingkat perilaku personal hygiene disajikan pada tabel berikut :

Tabel 7 Tingkat Perilaku Personal Hygiene Ibu

\begin{tabular}{clcc}
\hline No. & Perilaku personal hygiene & Jumlah & Persentase (\%) \\
\hline 1 & Baik & 11 & 14,7 \\
2 & Cukup & 30 & 40,0 \\
3 & Kurang & 34 & 45,3 \\
& Total & 75 & $100.0 \%$ \\
\hline
\end{tabular}

Berdasarkan tabel 7 diketahui bahwa sebagian besar responden mempunyai perilaku personal hygiene yang kurang sebanyak 34 responden $(45,3 \%)$. Untuk ibu yang mempunyai perilaku personal hygiene cukup sebanyak 30 responden $(40,0 \%)$ dan ibu yang berperilaku personal hygiene baik sebanyak 11 responden $(14,7 \%)$. Hal tersebut menunjukkan bahwa sebagian besar responden mempunyai perilaku personal hygiene kurang.

b. Kejadian Diare

Kejadian diare dalam penelitian ini di kelompokan menjadi dua yaitu “ya" dan "tidak".Distribusi kejadian diare disajikan pada tabel berikut : 
Tabel 8. Kejadian Diare Pada Balita di Desa Kaling

\begin{tabular}{|c|c|c|c|}
\hline No. & Kejadian Diare & Jumlah & Persentase (\%) \\
\hline 1 & Ya & 38 & 50.7 \\
\hline 2 & Tidak & 37 & 49.3 \\
\hline & Total & 75 & $100.0 \%$ \\
\hline
\end{tabular}

Berdasarkan tabel 8. diketahui bahwa balita di Desa Kaling Kecamatan Tasikmadu yang mengalami diare sebesar $50.7 \%$ lebih besar dibandingkan dengan balita yang tidak diare 49.3\%. Hal ini berarti bahwa sebagian besar balita di Desa Kaling Kecamatan Tasikmadu pernah mengalami diare.

4. Analisa Bivariat

Berdasarkan analisis data dengan menggunakan uji Chi- Square didapatkan hasil sebagai berikut :

Tabel 9. Analisis Data Hubungan Pengetahuan Perilaku Personal Hygiene Ibu dengan Kejadian Diare di Desa Kaling Kecamatan Tasikmadu

\begin{tabular}{|c|c|c|c|c|c|c|}
\hline \multirow{3}{*}{$\begin{array}{l}\text { Pengetahuan perilaku } \\
\text { personal hygiene ibu }\end{array}$} & \multicolumn{4}{|c|}{ Kejadian Diare } & \multirow{3}{*}{$X^{2}$} & \multirow{3}{*}{$\mathrm{p}$} \\
\hline & \multicolumn{2}{|c|}{$\mathrm{Ya}$} & \multicolumn{2}{|c|}{ Tidak } & & \\
\hline & $\mathrm{N}$ & $\%$ & $\mathrm{~N}$ & $\%$ & & \\
\hline Baik & 1 & 9.1 & 10 & 90.9 & 26.390 & 0.000 \\
\hline Cukup & 9 & 30.0 & 21 & 70.0 & & \\
\hline Kurang & 28 & 82.4 & 6 & 17.6 & & \\
\hline
\end{tabular}

Berdasarkan tabel 9 diatas diketahui bahwa responden yang mempunyai pengetahuan tentang personal hygiene yang baik, akan menerapkan perilaku personal hygiene yang baik pula dan efeknya adalah tidak mengalami diare sebesar 90,9\%, responden dengan pengetahuan perilaku personal hygiene yang cukup, maka balitanya tidak mengalami diare sebesar 70,0\% sedangkan responden dengan pengetahuan perilaku personal hygiene yang kurang maka balitanya pernah mengalami diare sebesar $82.4 \%$. Selanjutnya untuk mengetahui hubungan pengetahuan perilaku personal hygiene ibu dengan kejadian diare pada balita di Desa Kaling Kecamatan Tasikmadu digunakan analisis uji Chi-Square didapatkan nilai $X^{2}$ hitung sebesar 26.390 sedangkan $X^{2}$ tabel pada df $=2$ sebesar 5,991 sehingga $X^{2}$ hitung $>X^{2}$ tabel dan jika dilihat berdasarkan nilai $\mathrm{p}$ sebesar 0,000 berarti $\mathrm{p}<0,05$ sehingga dapat disimpulkan bahwa ada hubungan antara pengetahuan perilaku personal hygiene ibu dengan kejadian diare pada balita di Desa Kaling Kecamatan Tasikmadu.

Selanjutnya, sesuai dengan analisis data perilaku personal hygiene dengan kejadian diare, didapatkan hasil bahwa responden dengan perilaku baik, balitanya mengalami diare sebesar $9,1 \%$, sedangkan responden dengan perilaku personal hygiene cukup balitanya mengalami diare sebesar 30,0\% dan responden yang perilaku personal hygiene kurang, balitanya mengalami diare sebesar 82,4\%. Berdasarkan uji statistik chi-square yang didasarkan taraf kemaknaan yang ditetapkan $(\alpha \leq 0,05)$ dan didapatkan $\mathrm{p}=0,000$ dimana $\mathrm{p}<\alpha$ dan nilai $\mathrm{X}^{2}$ hitung 
sebesar 26.390 sedangkan $X^{2}$ tabel pada df $=2$ sebesar 5,991 sehingga $X^{2}$ hitung > $\mathrm{X}^{2}$ tabel maka hipotesis diterima jadi ada hubungan perilaku personal hygiene ibu dengan kejadian diare pada balita di Desa Kaling Kecamatan Tasikmadu. Secara teoritis kejadian diare dapat disebabkan oleh faktor lingkungan, pengetahuan ibu, sosial ekonomi, faktor infeksi, faktor malabsorpsi, faktor infeksi, faktor psikis dan faktor makanan (infeksi) sehingga dalam pengolahan makanan perlu diperhatikan hygiene perorangan untuk menjamin keamanan makanan dan untuk mencegah terjadinya penyebaran penyakit melalui makanan karena pada balita penularan penyakit diare dapat melalui fase oral terutama disebabkan karena menelan makanan yang terkontaminasi, kontak dengan tangan yang terkontaminasi dan penyiapan dan penyimpanan makanan yang tidak semestinya (Purnawijayanti, 2011).

Perilaku personal hygiene seseorang merupakan faktor yang berhubungan erat dengan kejadian diare. Perilaku personal hygiene yang tidak baik seperti kebiasaan mencuci tangan memakai sabun, penyiapan dan penyimpanan makanan yang tidak layak, kebersihan perorangan juga dapat mengakibatkan terjadinya diare . Hal ini sejalan dengan penelitian yang dilakukan Tangka, W (2014) yang menyatakan bahwa personal hygiene yang kurang baik lebih beresiko terjadi diare dan meningkatkan angka kejadian diare pada balita.

Penelitian Maharani (2013) dengan judul : "Personal hygiene ibu yang kurang berhubungan dengan kejadian diare pada balita di ruang anak", menunjukkan bahwa ada hubungan pola hygiene ibu dengan frekuensi kejadian diare pada balita, pola hygiene ibu yang tidak baik rata-rata kejadian diare 2,8 kali dalam satu tahun. Penelitian ini sejalan dengan penelitian yang dilakukan Linda (2017) dengan judul : "Hubungan personal hygiene ibu dan balita dengan kejadian diare pada balita di Desa Bareng Kabupaten Jombang", yang menunjukkan hasil terdapat hubungan yang signifikan antara kejadian diare dan personal hygiene.

Perilaku personal hygiene ibu yang kurang sangat berpengaruh terhadap kejadian diare pada balita, semakin baik perilaku personal hygiene ibu semakin rendah pula kejadian diare pada balita. Hal ini disebabkan karena balita rentan terhadap mikroorganisme dan berbagai agen infeksius yang dapat menyebabkan diare, sehingga perilaku personal hygiene ibu perlu diperhatikan untuk menurunkan terjadinya diare pada balita (Mokodompit A, 2015).

\section{SIMPULAN DAN SARAN}

\section{Simpulan}

Terdapat hubungan yang signifikan antara perilaku personal hygiene dengan kejadian diare balita di Desa Kaling Kecamatan Tasikmadu dengan $p$ value 0,000. Sebesar $50.7 \%$ balita di Desa Kaling Kecamatan Tasikmadu mengalami diare dan Sebesar $45.3 \%$ ibu di Desa Kaling Kecamatan Tasikmadu memiliki perilaku personal hygiene kurang. Semakin buruk perilaku personal hygiene ibu maka akan meningkatkan kejadian diare pada balita. 


\section{Saran}

Hasil penelitian ini diharapkan menjadi informasi yang dapat menambah pengetahuan bagi ibu yang memiliki anak balita di desa Kaling, Kecamatan Tasikmadu agar memahami dan menerapkan perilaku personal hygiene melalui kegiatan posyandu agar dapat memperhatikan mengenai pencegahan diare. Karena dengan perilaku personal hygiene seperti kebiasaan mencuci tangan, menjaga kebersihan kuku, menjaga kebersihan bahan makanan, kebiasaan memberi makan balita, serta bagi tenaga kesehatan diharapkan dapat meningkatkan penyuluhan diare terutama di tingkat posyandu dan PKK, mengingat pada tingkat ini dapat menjangkau masyarakat yang luas.

\section{DAFTAR PUSTAKA}

Alfarisi. 2008. Pentingnya Menjaga Kebersihan. Diakses 9 November 2018. http://www.wikimu.com/News/DisplayNews.asp?id=10187

Balitbang Kemenkes RI. 2013. Riset Kesehatan Dasar RISKESDAS. Jakarta: RISKESDAS.Daulay SNJ. 2017. Gambaran Sanitasi Lingkungan dan Personal Hygiene Ibu dengan Kejadian Diare pada Balita di Wilayah Kerja Puskesmas Tanjung Tiram Kabupaten Batubara [skripsi]. Medan: Fakultas Kesehatan Masyarakat USU.

Diah E. 2013. Personal Hygiene Penderita Diare di Wilayah UPT Puskesmas Gayaman Mojoanyar-Mojokerto. Jurnal Keperawatan. Vol 5.No.1,Maret 2013. Scholar.google.co.id.>citations. Diakses tanggal 9 November 2018.

Dinas Kesehatan Provinsi Jawa Tengah. 2016. Profil Kesehatan Jawa Tengah. Semarang: Dinas Kesehatan Provinsi JawaTengah.www.depkes.go.id $>13$ Jateng_2016. Diakses tanggal 16 oktober 2018.

Isroin L, Andarmoyo S. 2012. Personal Hygiene Konsep, Proses, dan Aplikasi dalam Praktik Keperawatan. Yogyakarta: Graha Ilmu. Hal : 2

Kusumasari R. 2015. Hubungan Perilaku Hidup Bersih Dan Sehat Ibu Dengan Kejadian Diare Pada Usia 3 Bulan - 2 Tahun Di Desa Pulosari Kecamatan Kebakkramat Kabupaten Karanganyar [Naskah Publikasi]. Surakarta: Fakultas Kedokteran UMS.

Lestari T. 2016. Asuhan Keperawatan Anak. Yogyakarta: Nuha Medika. Hal : 63 Linda.2017. Hubungan Personal Hygiene Ibu dan Balita Dengan Kejadian Diare Pada Balita di Desa Bareng Kecamatan Bareng Kabupaten Jombang. Jurnal Penelitian STIKES PEMKAB JOMBANG.

Mafazah L. 2013. Ketersediaan Sarana Sanitasi Dasar, Personal Hygiene Ibu Dan Kejadian Diare. Jurnal Kesehatan Masyarakat ISSN 1858-1196.

Maharani D. 2013. Personal Hygiene Ibu Yang Kurang Berhubungan Dengan Kejadian Diare Pada Balita Di Ruang Anak. Jurnal STIKES Volume 6, No. 1 Juli 2013

Mokodompit A. 2015. Hubungan Tindakan Personal Hygiene Ibu dengan Kejadian Diare pada Balita di Puskesmas Bilalang KotaMobagu. e-Journal Keperawatan (eKp) vol 3 Nomor 2 Oktober 2015. 
Ngastiyah. 2014. Perawatan Anak Sakit. Monica E, editor edisi ke-2. Jakarta: EGC. Hal : 223

Perry dan Potter. 2005. Buku Ajar Fundamental Keperawatan Konsep, Proses, dan Praktik. Jakarta: EGC.

Purnawijayanti A .2011. Sanitasi, Higiene dan Keselamatan Kerja Dalam Pengolahan Makanan. Yogyakarta : KANISIUS. Hal : 123

Purwandari R. 2013. Hubungan Antara Perilaku Mencuci Tangan Dengan Insiden Diare Pada Anak Usia Sekolah Di Kabupaten Jember. Jurnal Keperawatan, ISSN: 2086-3071

Sugiyono. 2017. Metode Penelitian Kuantitatif, Kualitatif, Dan R\&D. Bandung: Alfabeta. Hal : 87

Suparno. 2015. Faktor-Faktor yang berhubungan Dengan Kejadian Diare Pada Balita Di Kelurahan Saung Naga Kecamatan Baturaja Barat Tahun 2014. Jurnal Keperawatan Sriwijaya, Volume 2- Nomor1, Januari 2015, ISSN No 23555459.

Tangka W. 2014. Faktor-Faktor Yang Berhubungan Dengan Kejadian Diare Pada Anak Balita Di Puskesmas Bintauna Kabupaten Bolaang Mongondow Utara. Juperdo, vol 3, No. 2 September 2014.

Wartonah, Tarwoto. 2006. Kebutuhan Dasar Manusia dan Proses Keperawatan. Jakarta: Salemba Medika. 